\section{Endomyocardial biopsy in Chagas' heart disease: pathogenetic contributions}

\author{
Heart Institute, Hospital das Clínicas, Faculdade de Medicina da \\ Universidade de São Paulo - São Paulo, Brazil
}

\begin{abstract}
Endomyocardial biopsy procedure has been performed in many centers around the world, allowing a better treatment and followup of the patients with myocardial disease. In Chagas' disease, it has been performed in São Paulo Heart Institute since 1978 and has brought important contributions to the understanding of the disease and consequently of the patient's clinical stage. In the present work we summarize the principal findings regarding the pathogenesis of Chagas' disease obtained mainly from the studies using endomyocardial biopsy specimens. Nowadays we do not have doubts that the inflammatory infiltrate aggressing myocardial fibers has fundamental role in the progression of the myocardial damage in Chagas' disease what culminates in chronic heart failure. The parasite seems to have active participation in the maintenance of such myocardial inflammation.
\end{abstract}

UNITERMS: Endomyocardial biopsy. Chagas' disease. Pathogenesis. Trypanosoma cruzi. Immunopathology.

\section{INTRODUCTION}

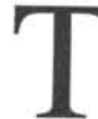

he low levels of morbidity and mortality of endomyocardial biopsy technique have made very common its use in several conditions. This technique was described by Konno e Sakakibara in 1963 (10) and the main indication has been the detection earliest as possible acute rejection episodes in the follow-up of heart transplanted patients. Frequently, more than 20

\footnotetext{
Addres 'or correspondence:

Maria de Lourdes Higuchi

Instituto do Coração - Hospital das Clínicas da Faculdade de Medicina da Universidade de São Paulo

Av. Dr. Enéas de Carvalho Aguiar, 44

São Paulo - SP - Brasil - CEP 05403-000
}

consecutives endomyocardial biopsies are performed in a same patient (17). It has also being used for the diagnosis and control of the treatment of myocarditis.

Employment of the endomyocardial biopsy has provided many important contributions in the understanding of the pathogenesis of chronic Chagas' disease and it may be, in the future, an important auxiliary procedure in the monitorization of the treatment of chronic chagasic patients.

The lack of reliable anatomopathological data, mainly regarding the indeterminate stage, has created difficulties in the understanding of the heart failure in chronic Chagas' disease. Lopes et al., in 1975 published one of the few morphological works about the indeterminate form before the introduction of the endomyocardial biopsy technique, and showed that chronic chagasic patients who had died due to sudden death, frequently presented mild chronic inflammatory infiltrate in the heart (11). 
The introduction of endomyocardial biopsy technique permitted to demonstrate variable degrees of anatomopathological alterations in $60 \%$ of the chagasic patients in the indeterminate form, that is patients without cardiac clinical symptoms, radiological or eletrocardiographical alterations (12).

Carrasco-Guerra et al., in 1987 (2), also observed that $60 \%$ of the patients with no evidence of myocardial disfunction (indeterminate form) presented degenerative alterations detected by optical microscopy, ultrastructural analysis or histochemical study. There was major incidence and more severity of such abnormalities in the groups of patients with eletrocardiographic abnormalities. The authors proposed a new classification for chronic Chagas' disease, using endomyocardial biopsy, cineventriculogram, and grade of heart failure: zero (normal cineventriculogram and normal biopsy), IA (normal ECG and normal cine, but abnormal biopsy), IB (normal ECG, abnormal cine and abnormal biopsy), II (abnormal ECG, abnormal cine and abnormal biopsy, without heart failure) and III (abnormal ECG, abnormal cine and abnormal biopsy with congestive heart failure).

Palácios - Prü et al. (16), quantified the myocardial ultraestructural alterations and observed an increase of such lesions from grade I-A untill grade II. There was a mild decrease of the lesions in the grade III.

Pereira-Barreto et al., in 1986 (18), studied endomyocardial biopsy specimens form chronic chagasic patients in different clinical stages (indeterminate, cardiac form without heart failure and cardiac form with heart failure) and demonstrated that hypertrophy and fibrosis were more frequent and more severe in the group of patients with heart failure. The inflammatory infiltrate was present in nearly $65 \%$ of the patients with electrocardiographic alterations (with or without heart failure) and in $37 \%$ of the patients in the indeterminate form. Higuchi et al. (6), studied endomyocardial biopsy specimens from the same groups of patients looking for active myocarditis. In this work the authors used as criterium of active myocarditis the presence of lymphocytes surrounding myocardial fibers which were interpreted as foci of myocardial aggression. They concluded that myocarditis is more frequent and more severe in the group with chronic heart failure (92\%), secondly in the group without heart failure $(62 \%)$ and rarely in the indeterminate form $(15 \%)$.

All of these findings reinforced the idea that the inflammation, mainly attacking the myocardial fibers, has a fundamental role in the evolution of the chronic chagasic cardiopathy to heart failure. The clinical evolution of the disease would represent a continuous progression of myocardial fibers destruction, substitution by fibrosis, compensatory hipertrophy, cardiac dilatation and heart failure.

The active participation of the inflammatory process in the pathogenesis of chronic cardiac Chagas' disease was contested in the past (9). However, nowadays, most of the investigators believe that immunological reactions should be involved in this process. The discrepancy between presence of parasites and intensity of inflammatory infiltrate and the difficulty to find $T$. cruzi parasites originated many autoimmune or hipersensitivity theories.

The finding of circulating autoantibodies in chronic chagasic patients suggested participation of humoral autoimmune phenomenon (3). Corroborating this idea Molina et al. (14), in 1984, detected IgG, IgA, IgM and C3 in the interstitium, capilar, endocardium and surface of cardiac fibers using endomyocardial biopsy in chronic chagasic patients, and direct immunofluorescent and immunohistochemical studies. However, Higuchi et al. (8) did not any find immunoglobulins or complement in the myocardium of endomyocardial biopsy specimens from chronic chagasic patients presenting heart failure, also using immunofluorescence technique contradicting the idea of direct participation of autoantibodies in the pathogenesis of chronic chagasic myocarditis.

The involvement of cellular autoimunity was investigated by Higuchi et al. (7), through the detection of which subsets of $\mathrm{T}$ cells were participating in chronic chagasic myocarditis and comparing with the myocardial rejection process in non-chagasic heart transplanted patients. The authors considered that the rejection could be seen as an autoimmune process, since it is a reaction of the lymphocytes against myocardial fibers which are considered as non-self. The myocardial rejection process was characterized by similar numbers of CD8+ and CD4+ $\mathrm{T}$ cells. In contrast, the chronic chagasic myocarditis was characterized as a $\mathrm{T}$ cell myocarditis, mainly by $\mathrm{CD} 8+$ and scarce and weakly stained CD4+ cells. The authors suggested participation of the parasite inducing weak expression of CD4 $\mathrm{T}$ cells experimental acute infection since it is known experimentally that $T$. cruzi is able to decrease the expression of surface $\mathrm{CD}$ molecules, causing a immunodepression in the host (20).

In spite of some experimental works have suggested the possibility of development of chronic cardiopathy only injecting fragments of the parasite and consequently the disease to be associated to an auto-immune process (21), the real significance of the parasite in the pathogenesis of chronic lesions of Chagas' disease is demanding more studies. Recently we studied this matter in autopsy material 


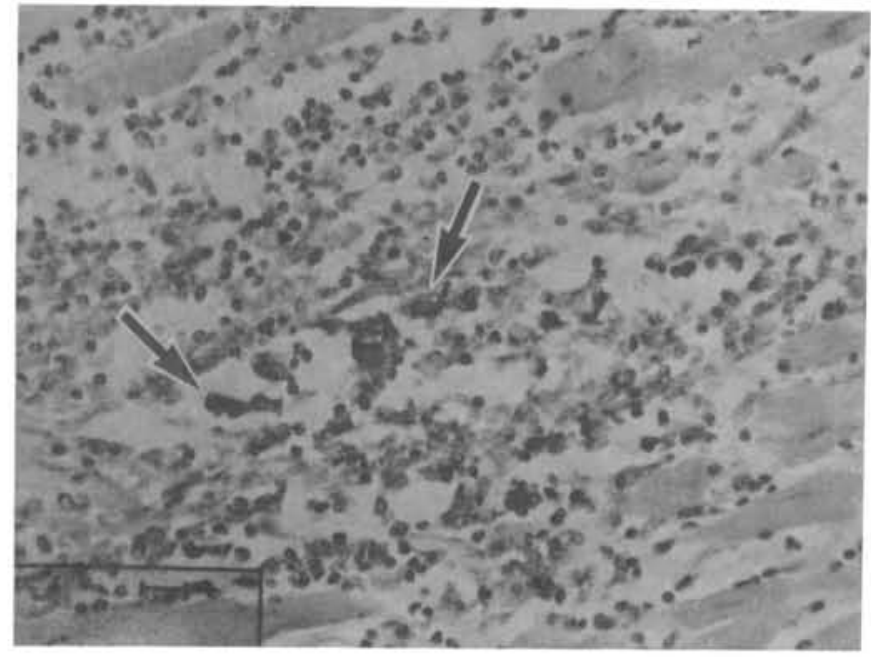

Figure 1. Histopathological picture of human chronic chagasic myocarditis exhibiting intracellular $T$. cruzi antigens, detected by specific immunohistochemical reaction. (IPX 160x)

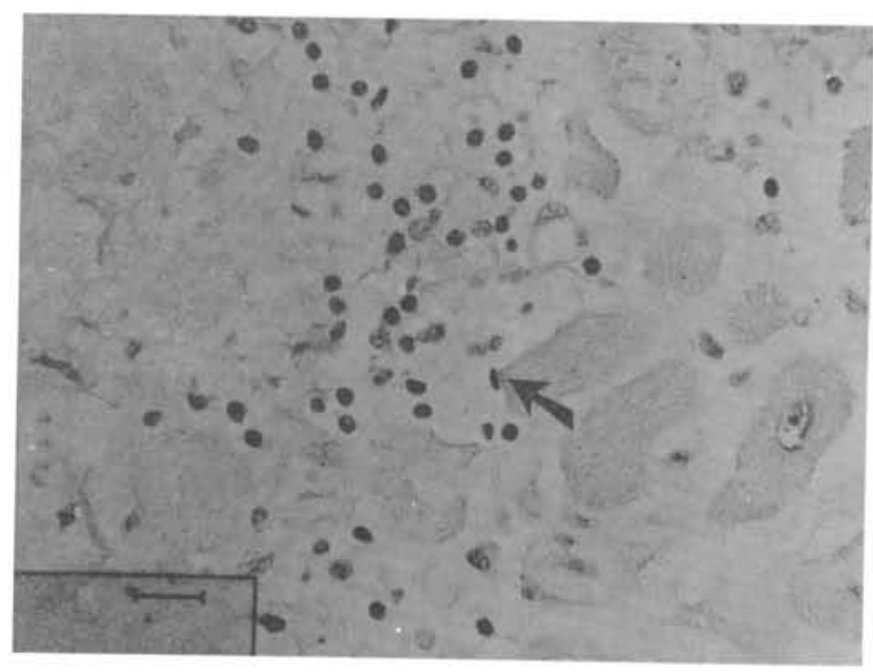

Figure 2. Histopathological aspect from another human case of chronic chagasic myocarditis showing three degenerated T. cruzi amastigotes (through immunoperoxidasis technique) near to the sarcolemma of a myocardial fiber surrounded by moderate mononuclear inflammatory infiltrate. (IPX 400x)

(1) produced chronic myocarditis in guinea-pigs injecting homogenates of heart associated to T. cruzi antigen and Freund adjuvant, concluding that hipersensitivity had a fundamental role in the pathogenesis of this myocarditis. Franco, in 1972 (4), analysed acute and chronic infection in guinea-pigs and verified presence of $T$. cruzi antigens in macrophages during also the chronic stage of the disease, suggesting that the persistence of these antigens in interstitial macrophages would induce the hipersensitivity reactions. Another data favouring the concept of chronic influence of the parasite comes from the observation of chronic chagasic patients submitted to heart transplantation. These patients frequently present episodes of reactivation of the Chagas' disease after immunosuppression (19) indicating that the parasite remains in constant immunological control in chronic phase of the disease. Than, if myocarditis occurs in the endomyocardial biopsies of these patients, it is necessary to search $T$. cruzi antigens at the myocardial sections in order to differentiate myocardial rejection process from chronic chagasic myocarditis, because both processes have the same histological feature. In case of Chagas' disease reactivation, treatment with specific antiparasitic drug determinates a fast disappearance of the inflammatory 
infiltrate. After all these findings we are convinced that parasite has significant influence in determining the active chronic myocarditis and that the endomyocardial biopsy may have important role in the follow up of these patients. In our oppinion, chronic chagasic patient with moderate or severe inflammation at the endomyocardial biopsy probably presents any grade of $T$. cruzi reactivation, and new therapeutic purposes should be developed in order to prevent aggravation of the process.

\section{Resumo}

O procedimento de biópsia endomiocárdica vem sendo realizado em vários centros do mundo possibilitando melhor acompanhamento e tratamento dos pacientes com doenças do miocárdio. Em relação à doença de Chagas, este procedimento vem sendo executado no Instituto do Coração desde 1978 e tem trazido importantes contribuiçōes no conhecimento da doença e consequ̇entemente do estado clínico do paciente. No presente trabalho resumimos os principais avanços em relaçấo à patogenia da doença de Chagas, propiciados principalmente pelos estudos com a biópsia endomiocárdica. Hoje não se tem mais dúvidas de que o infiltrado inflamatório com agressão às fibras miocárdicas tem papel fundamental na progressāo do comprometimento miocárdico até levar à insuficiência cardiaca congestiva. O parasita parece ter participação ativa na perpetuação desta inflamação miocárdica. 


\section{REFERENCES}

1. BRITO, T. - Miocardite "alérgica" do cobaio e sua possível relação com a cardite chagásica experimental. São Paulo, 1962 [Tese Doutoramento - Universidade de São Paulo].

2. CARRASCO GUERRA, H.A.; PALÁCIOS-PRÜ, E.; SCORZA, C.D.; MOLINA, C.; INGLESSIS, G. \& MENDOZA, R.V. - Clinical, histochemical and ultrastructural correlation in septal endomyocardial biopsies from chronic chagasic patients: Detection of early myocardial damage. Am Heart J 113:716-24, 1987.

3. COSSIO, P.M.; DIEZ, D.; SZARFMAN, A. \& ARANA, R.M. - Chagasic cardiopathy. Demonstration of a serum gamma globulin factor which reacts with endocardium and vascular structures. Circulation 49: 13-21, 1974.

4. FRANCO, M.F. - Experimental carditis induced by Trypanosoma cruzi (Y strain) in guinea pigs: correlation between histopathology and the presence of T cruzi antigens identified by indirect immunofluorescence. Rev Soc Bras Med Trop 23:187-89, 1990.

5. HIGUCHI, M.L.; BRITO, T.; REIS, M.M. et al. - Correlation between Trypanosoma cruzi parasitism and myocardial inflammatory infiltrate in human chronic chagasic myocarditis. Light microscopy and immunohistochemical findings. Cardiovasc Pathol 2:101-6, 1993.

6. HIGUCHI, M.L.; DE MORAIS, C.F.; PEREIRABARRETO, A.C. et al. - The role of active myocarditis in the development of heart failure in chronic Chagas' disease: a study based on endomyocardial biopsies. Clin Cardiol 10:665-70, 1987.

7. HIGUCHI, M.L.; GUTIERREZ, P.S.; AIELLO, V.D. et al. Immunohistochemical characterization of infiltrating cells in human chronic chagasic myocarditis: comparison with myocardial rejection process. Virchows Archiv A Pathol Anat 423:157-60, 1993.

8. HIGUCHI, M.L.; LOPES, E.A.; SALDANHA, L.B. et al. Immunopathologic studies in myocardial biopsies of patients with Chagas' disease and idiopathic cardiomyopathy. Rev Inst Med Trop São Paulo 28: 87-90, 1986.

9. KOBERLE, F, - Cardiopatia chagásica. Hospital (Rio de Janeiro) 53: 311-46, 1958.
10. KONNO, S. \& SAKAKIBARA, S. - Endomyocardial biopsy. Dis Chest 44:345-50, 1963.

11. LOPES, E.R.; CHAPADEIRO, E.; ALMEIDA, H.O. \& ROCHA, A. - Contribuição ao estudo da anatomia patológica dos corações de chagásicos falecidos subitamente. Rev Soc Bras Med Trop 6: 269-82, 1975.

12. MADY, C.; PEREIRA, A.; STOLF, N. et al. - Right ventricular endomyocardial biopsy in undetermined form of Chagas' disease. Angiology 35:755-8, 1984.

13 MAGARINO-TORRES, C.B. - Patogenia de la miocardite cronica de la "enfermedad de Chagas". Quinta Reunión de la Sociedad Argentina de Patologia Regional do Norte 2: 902-16, 1929.

14. MOLINA, H.A.; MILEI, J. \& STORINO, R. - Chronic Chagas' myocardiopathy. Demonstration of in vivo bound immunoglobulins in heart structures by the immunoperoxidase technique. Cardiology 71:297-306, 1984.

15. MUNIZ, J. \& AZEVEDO, A.P. - Novo conceito da patogenia da Doença de Chagas. Hospital (Rio de Janeiro) 32: 165 $83,1977$.

16. PALÁCIOS-PRÜ, E.; CARRASCO, H.; SCORZA, C. \& ESPINOZA, R. - Ultrastructural characteristics of different stages of human chagasic myocarditis. Am J Trop Med Hyg 4: 29-40, 1989.

17. PEREIRA-BARRETO, A.C.; COSTA, R.; HIGUCHI, M.L. et al. - Biópsia endomiocárdica do ventrículo direito - 9 anos (1978-1987). Arq Bras Cardiol 49: 147-9, 1987.

18. PEREIRA-BARRETO, A.C.; MADY, C.; ARTEAGAFERNANDEZ, E. et al. - Right ventricular endomyocardial biopsy in chronic Chagas' disease. Am Heart J 111:307-12, 1986.

19. STOLF, N.A.; HIGUCHI, M.L.; BOCCHI, E. et al. - Heart transplantation in patients with Chagas' disease cardiomyopathy. J Heart Transpl 6:307-12, 1987.

20. SZTEIN, M.; WASHINGTON, R.C. \& KIERSZENBAUM, F. - Trypanosoma cruzi inhibits the expression of CD3, CD4, CD8 and IL-2R by mitogen-activated helper and cytotoxichuman lymphocytes. J Immunol 144: 3558-62, 1990.

21. TEIXEIRA, A.R.L.; TEIXEIRA, M.L. \& SANTOS BUCH, C.A. - The immunology of experimental Chagas'disease. IV. Production of lesions in rabbits similar to those of chronic Chagas'disease in man. Am J Path 80: 163-180, 1975. 